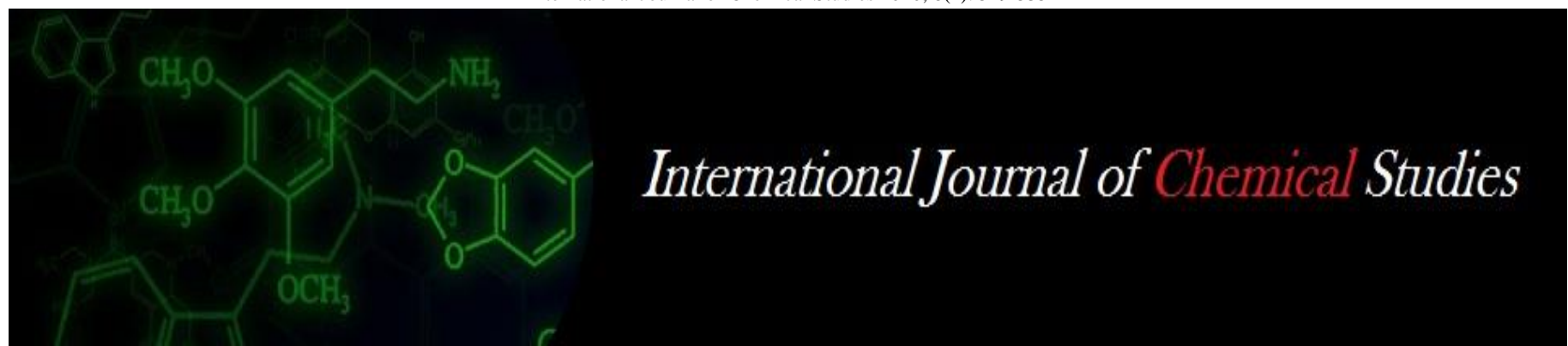

P-ISSN: 2349-8528

E-ISSN: 2321-4902

IJCS 2020; 8(1): 529-535

(C) 2020 IJCS

Received: 07-11-2019

Accepted: 09-12-2019

YA Waghmare

Student, College of Agriculture

Vasantrao Naik Marathwada

Krishi Vidyapeeth Parbhani,

Maharashtra, India

\section{AL Dhamak}

Associate, Soil Science and Agricultural Chemistry, College of Agriculture, Vasantrao Naik Marathwada Krishi Vidyapeeth Parbhani, Maharashtra, India

Syed Ismail

HOD, Department of Soil Science and Agricultural Chemistry, College of agriculture, Vasantrao Naik Marathwada Krishi Vidyapeeth Parbhani, Maharashtra, India
Corresponding Author: YA Waghmare

Student, College of Agriculture, Vasantrao Naik Marathwada Krishi Vidyapeeth Parbhani, Maharashtra, India

\section{Impact of levels of zinc and various zinc solubilizing microorganisms on changes in zinc and other soil nutrients in spinach}

\author{
YA Waghmare, AL Dhamak and Syed Ismail
}

DOI: https://doi.org/10.22271/chemi.2020.v8.i1h.8313

\begin{abstract}
Field experiment was conducted during kharif season of 2018 at Research farm, Department of Soil Science and Agricultural Chemistry, Vasantrao Naik Marathwada Krishi Vidyapeeth, Parbhani to assess the response of spinach crop to various zinc solubilizers and graded levels of zinc on changes in zinc and other soil nutrients. Experiment consists of sixteen treatment in which four zinc solubilizers (Pseudomonas striata, Bacillus megaterium, Trichoderma viride and Control) and four graded levels of $\mathrm{ZnSO}_{4}\left(0 \mathrm{~kg} \mathrm{ZnSO}_{4} \mathrm{ha}^{-1}, 10 \mathrm{~kg} \mathrm{ZnSO}_{4} \mathrm{ha}^{-1}, 20 \mathrm{~kg} \mathrm{ZnSO}_{4} \mathrm{ha}^{-1}\right.$ and $\left.30 \mathrm{~kg} \mathrm{ZnSO}_{4} \mathrm{ha}^{-1}\right)$ were used in factorial randomized block design. Seed treatment of spinach was done with zinc solubilizing microbial cultures and application of zinc in graded doses at the time of sowing with recommended dose of fertilizers. Significantly highest values of available N, $\mathrm{P}_{2} \mathrm{O}_{5}, \mathrm{~K}_{2} \mathrm{O}$ and $\mathrm{S}$ were noted in treatment receiving Psuedomonas striata $+30 \mathrm{~kg} \mathrm{ZnSO}_{4} \mathrm{ha}^{-1}$ interaction. DTPA $\mathrm{Zn}, \mathrm{Fe}, \mathrm{Mn}$ and $\mathrm{Cu}$ were noted maximum in treatment receiving Psuedomonas striata $+30 \mathrm{~kg} \mathrm{ZnSO}_{4} \mathrm{ha}^{-1}$.
\end{abstract}

Keywords: Spinach, zinc solubilizers, zinc levels

\section{Introduction}

Spinach (Spinacea oleracea L.) is one of the perennial leafy vegetable and grown throughout the world. Spinach has an excellent nutritional values and health benefits. Farmers can grow this crop in greenhouse, polyhouse and hygroscopic system as well. It can be grown for daily use in pots, containers, backyards also in field. Spinach belongs to family of 'Chenopodiaceae' and genus of 'Spinacea'. Raw spinach has 91\% water, $4 \%$ carbohydrates, $3 \%$ protein, and contains negligible fat. In a $100 \mathrm{~g}$ serving providing only 23 calories, spinach has a high nutritional value, especially when fresh, frozen, steamed, or quickly boiled.

Zinc plays very important role in plant metabolism by influencing the activities of hydrogenase and carbonic anhydrase, stabilization of ribosomal fractions and synthesis of cytochrome. Plant enzymes activated by $\mathrm{Zn}$ are involved in carbohydrate metabolism, maintenance of the integrity of cellular membranes, protein synthesis, regulation of auxin synthesis and pollen formation. The regulation and maintenance of the gene expression required for the tolerance of environmental stresses in plants are $\mathrm{Zn}$ dependent. Its deficiency results in the development of abnormalities in plants which become visible as deficiency symptoms such as stunted growth, chlorosis and smaller leaves, spikelet sterility. Zinc deficiency can also adversely affect the quality of harvested products, plants susceptibility to injury by high light or temperature intensity and to infection by fungal diseases can also increases. Zinc seems to affect the capacity for water uptake and transport in plants and also reduce the adverse effects of short periods of heat and salt stress (Hafeez et al. 2013) ${ }^{[9]}$.

Availability of zinc to plants can be increases by zinc-solubilizing microorganisms through solubilize zinc from inorganic and organic pools of total soil zinc. Both in vitro and in vivo fungi have been extensively studied for solubilization of insoluble zinc compounds (Gadd. 2007) ${ }^{[17]}$. However, only some bacterial species of the genera Bacillus, Acinetobacter, Gluconacetobacter, and Pseudomonas have been reported (Simine, et al. 1998) ${ }^{[18]}$. For zinc solubilization microorganisms play a key role. Some species of rhizobacteria are capable of solubilizing zinc in accessible form in soils. Mineral zinc solubilization by microbes which enhances crop growth and yield. Zinc solubilizing bacteria are capable of solubilizing $\mathrm{ZnO}$, 
$\mathrm{ZnCO}_{3}$ and zinc phosphate through production and excretion of organic acids. Several genera of rhizobacteria belonging to Pseudomonas spp. and Bacillus spp. are reported to solubilize zinc. Microbes solubilize the metal forms by protons, chelated ligands and oxidoreductive systems present on the cell surface and membranes. These bacteria also exhibit other traits beneficial to plants, such as production of phytohormones, antibiotics, siderophores, vitamins, antifungal substances and hydrogen cyanide (Goteti et al. 2013) ${ }^{[8]}$. Microorganisms are capable for zinc solubilization viz., B. subtilis, Thiobacillus thioxidans and Saccharomyces sp. These microorganisms can be used as bio-fertilizers for solubilization of fixed micronutrients like zinc. The results have shown that a Bacillus sp. (Zn solubilizing bacteria) can be used as biofertilizer for zinc or in soils where native zinc is higher or in conjunction with insoluble cheaper zinc compounds like zinc oxide $(\mathrm{ZnO})$, zinc carbonate $\left(\mathrm{ZnCO}_{3}\right)$ and zinc sulphide $(\mathrm{ZnS})$ instead of costly zinc sulphate (Mahdi et al. 2010) ${ }^{[14]}$.

\section{Materials and Method}

The field experiment was carried out on spinach crop (Var. All green) in kharif season during year 2018 on Typic haplusters at Research Farm, Department of Soil Science and Agricultural Chemistry, Vasantrao Naik Marathwada Krishi Vidyapeeth, Parbhani. After completion of preparatory tillage operations, the experiment was laid out in Factorial Randomized Block Design comprising sixteen (16) treatments replicated three (3) times. In which four zinc solubilizers (Pseudomonas striata, Bacillus megaterium, Trichoderma viride and Control) and four graded levels of $\mathrm{ZnSO}_{4}(0 \mathrm{~kg}$
$\mathrm{ZnSO}_{4} \mathrm{ha}^{-1}, 10 \mathrm{~kg} \mathrm{ZnSO}_{4} \mathrm{ha}^{-1}, 20 \mathrm{~kg} \mathrm{ZnSO}_{4} \mathrm{ha}^{-1}$ and $30 \mathrm{~kg}$ $\mathrm{ZnSO}_{4} \mathrm{ha}^{-1}$ ). Seed treatment was done immediately before sowing with liquid zinc solubilizing culture @ $100 \mathrm{ml} 10 \mathrm{~kg}^{-1}$ seed. The crop was raised following recommended agronomic practices. The recommended dose of chemical fertilizers was applied at the time of sowing. Intercultural operations like thinning, weeding, spraying of insecticides, fertilizer application and schedule of irrigation for spinach crop was carefully followed.The data obtained was statistically analyzed and appropriately interpreted as per the methods described in "Statistical Methods for Agricultural Workers" by Panse and Sukhatme.

\section{Results and Discussion Nitrogen}

Perusal of data presented in Table 1 indicate that available $\mathrm{N}$ in soil was significantly increased with inoculation of different zinc solubilizing microbial inoculants in spinach. Zinc solubilizers influenced the available nitrogen which ranged between 166.07 to $186.80 \quad \mathrm{~kg} \mathrm{ha}^{-1}$ showing significantly higher available nitrogen in Pseudomonas striata treated plots followed by Bacillus megaterium and Trichoderma viride. Whereas, significantly lower available nitrogen per plot were noted in uninoculated control. Similarly, graded levels of zinc in the form of zinc sulphate also increase the available nitrogen with each incremental dose up to $30 \mathrm{~kg} \mathrm{ZnSO}_{4} \mathrm{ha}^{-1}$. The available nitrogen as influenced by $\mathrm{Zn}$ application ranged from 155.78 to $188.83 \mathrm{~kg}$ $\mathrm{ha}^{-1}$.

Table 1: Effect of zinc solublizing cultures and zinc levels on nutrient availability in spinach

\begin{tabular}{|c|c|c|c|c|}
\hline Treatments & Available N $\left(\mathrm{Kg} \mathrm{ha}^{-1}\right)$ & Available $\mathrm{P}_{2} \mathrm{O}_{5}\left(\mathrm{Kg} \mathrm{ha}^{-1}\right)$ & Available $\mathrm{K}_{2} \mathrm{O}\left(\mathrm{Kg} \mathrm{ha}^{-1}\right)$ & Available $S\left(\mathrm{mg} \mathrm{kg}^{-1}\right)$ \\
\hline \multicolumn{5}{|l|}{ Zinc solubilizers (S) } \\
\hline S0: Control & 166.07 & 15.61 & 584.38 & 10.11 \\
\hline S1: Pseudomonas striata & 186.80 & 18.46 & 634.86 & 11.04 \\
\hline S2: Trichoderma viride & 171.09 & 16.51 & 605.07 & 10.61 \\
\hline S3: Bacillus megaterium & 174.27 & 17.13 & 623.74 & 10.69 \\
\hline S.Em. \pm & 2.41 & 0.22 & 6.63 & 0.08 \\
\hline C.D. at $5 \%$ & 6.97 & 0.63 & 19.16 & 0.25 \\
\hline \multicolumn{5}{|l|}{ Levels of $\mathrm{ZnSO}_{4}(\mathrm{Zn})$} \\
\hline $\mathrm{Zn0:} \mathrm{ZnSO}_{4} 0 \mathrm{~kg} \mathrm{ha}^{-1}$ & 155.78 & 14.89 & 579.45 & 9.69 \\
\hline $\mathrm{Zn} 1: \mathrm{ZnSO}_{4} 10 \mathrm{~kg} \mathrm{ha}^{-1}$ & 171.45 & 17.34 & 600.48 & 10.57 \\
\hline $\mathrm{Zn} 2: \mathrm{ZnSO}_{4} 20 \mathrm{~kg} \mathrm{ha}^{-1}$ & 182.16 & 18.26 & 626.33 & 10.74 \\
\hline Zn3: $\mathrm{ZnSO}_{4} 30 \mathrm{~kg} \mathrm{ha}^{-1}$ & 188.83 & 18.53 & 641.79 & 10.90 \\
\hline S.Em. \pm & 2.41 & 0.22 & 6.63 & 0.08 \\
\hline C.D. at $5 \%$ & 6.97 & 0.63 & 19.16 & 0.25 \\
\hline \multicolumn{5}{|l|}{ Interaction (SxZn) } \\
\hline S.Em. \pm & 4.83 & 0.44 & 13.27 & 0.17 \\
\hline C.D. at $5 \%$ & 13.94 & 1.27 & 38.33 & 0.50 \\
\hline
\end{tabular}

Interaction effect of zinc solubilizing cultures and zinc levels on available $\mathrm{N}$ in Table 1a. Synergistic effect of each factor was recorded showing significantly highest available nitrogen in Pseudomonas striata $\mathrm{X} \mathrm{ZnSO}_{4} 30 \mathrm{~kg} \mathrm{ha}^{-1}\left(205.11 \mathrm{~kg} \mathrm{ha}^{-1}\right)$ it was found at par with Bacillus megaterium $\mathrm{X} \mathrm{ZnSO}_{4} 30 \mathrm{~kg}$ $\mathrm{ha}^{-1}$. However the lower values of available nitrogen $(140.74$ $\mathrm{kg} \mathrm{ha} \mathrm{h}^{-1}$ ) were recorded in without microbial inoculant and zinc application.
The increase in available nitrogen might also be attributed to the greater mobilization of soil microbes which converts organically bound $\mathrm{N}$ to inorganic form. The zinc solubilizing organism (Bacillus spp.) proved to have a favourable effect on the availability of $\mathrm{N}, \mathrm{P}$ and $\mathrm{K}$, thereby indicating vital role of these organisms in the transformation reaction of major nutrients in the soil. Experimental results are in corroborate with the findings of Kumar et al. (2004) ${ }^{[12]}$, Rizvi et al. (2013) ${ }^{[16]}$ and Sable et al. (2016) ${ }^{[17]}$. 
Table 1a: Interaction effect of zinc solubilizers and levels of zinc on nutrient availability in soil

\begin{tabular}{|c|c|c|c|c|c|}
\hline Treatments & $\mathrm{Zn0}^{2} \mathrm{ZnSO}_{4} \mathrm{O} \mathrm{kg} \mathrm{ha}^{-1}$ & $\mathrm{Zn1} \mathrm{ZnSO}_{4} 10 \mathrm{~kg} \mathrm{ha}^{-1}$ & $\mathrm{Zn2:ZnSO}_{4} 20 \mathrm{~kg} \mathrm{ha}^{-1}$ & $\mathrm{Zn3:ZnSO}_{4} 30 \mathrm{~kg} \mathrm{ha}^{-1}$ & Mean \\
\hline \multicolumn{6}{|c|}{ Available N $\left(\mathrm{kg} \mathrm{ha}^{-1}\right)$} \\
\hline S0: Control & 140.74 & 163.30 & 178.73 & 181.49 & 166.06 \\
\hline S1: Pseudomonas striata & 156.95 & 185.58 & 199.58 & 205.11 & 186.80 \\
\hline S2: Trichoderma viride & 159.65 & 168.18 & 173.79 & 182.76 & 171.09 \\
\hline S3: Bacillus megaterium & 165.79 & 168.76 & 176.55 & 185.76 & 174.26 \\
\hline Mean & 155.78 & 171.45 & 182.16 & 188.82 & \\
\hline Interaction & $\mathbf{S}$ & Zn & SXZn & & \\
\hline SEm+ & 2.41 & 2.41 & 4.83 & & \\
\hline CD at $5 \%$ & 6.97 & 6.97 & 13.94 & & \\
\hline \multicolumn{6}{|c|}{ Available $\mathrm{P}_{2} \mathrm{O}_{5}\left(\mathrm{~kg} \mathrm{ha}^{-1}\right)$} \\
\hline S0: Control & 12.91 & 16.33 & 17.79 & 17.80 & 15.61 \\
\hline S1: Pseudomonas striata & 16.54 & 18.78 & 19.17 & 19.30 & 18.46 \\
\hline S2: Trichoderma viride & 15.24 & 17.03 & 18.29 & 18.71 & 16.51 \\
\hline S3: Bacillus megaterium & 15.25 & 17.22 & 17.77 & 18.28 & 17.13 \\
\hline Mean & 14.89 & 17.34 & 16.78 & 18.53 & \\
\hline Interaction & $\mathbf{S}$ & $\mathbf{Z n}$ & SXZn & & \\
\hline SEm+ & 0.22 & 0.22 & 0.44 & & \\
\hline $\mathrm{CD}$ at $5 \%$ & 0.63 & 0.63 & 1.27 & & \\
\hline \multicolumn{6}{|c|}{ Available $\mathrm{K}_{2} \mathrm{O}\left(\mathrm{kg} \mathrm{ha}^{-1}\right)$} \\
\hline S0: Control & 517.43 & 552.51 & 624.33 & 643.25 & 584.38 \\
\hline S1: Pseudomonas striata & 602.83 & 627.18 & 652.24 & 657.18 & 634.85 \\
\hline S2: Trichoderma viride & 591.98 & 604.09 & 609.00 & 615.20 & 605.06 \\
\hline S3: Bacillus megaterium & 605.55 & 618.15 & 619.74 & 651.52 & 623.73 \\
\hline Mean & 579.44 & 600.48 & 626.32 & 641.89 & \\
\hline Interaction & $\mathbf{S}$ & Zn & SXZn & & \\
\hline $\mathrm{SEm}+$ & 6.63 & 6.63 & 13.27 & & \\
\hline CD at $5 \%$ & 19.16 & 19.16 & 38.33 & & \\
\hline \multicolumn{6}{|c|}{ Available $S\left(\mathrm{mg} \mathrm{kg}^{-1}\right)$} \\
\hline S0: Control & 8.30 & 10.26 & 10.84 & 11.05 & 10.11 \\
\hline S1: Pseudomonas striata & 10.31 & 10.96 & 11.12 & 11.15 & 11.04 \\
\hline S2: Trichoderma viride & 9.89 & 10.43 & 10.69 & 11.33 & 10.61 \\
\hline S3: Bacillus megaterium & 10.28 & 10.58 & 10.77 & 11.32 & 10.69 \\
\hline Mean & 9.69 & 10.57 & 10.74 & 10.90 & \\
\hline Interaction & $\mathbf{S}$ & $\mathbf{Z n}$ & SXZn & & \\
\hline SEm+ & 0.08 & 0.08 & 0.17 & & \\
\hline CD at $5 \%$ & 0.25 & 0.25 & 0.50 & & \\
\hline
\end{tabular}

\section{Phosphorus}

Available $\mathrm{P}_{2} \mathrm{O}_{5}$ in soil was influenced significantly due to various treatments of zinc solubilizing microbial inoculants in spinach are presented in Table 1 Zinc solubilizers influenced the available phosphorus which ranged from 15.61 to 18.46 $\mathrm{kg} \mathrm{ha}^{-1}$ showing significantly higher available phosphorus in Pseudomonas striata $\left(18.46 \mathrm{~kg} \mathrm{ha}^{-1}\right)$ treated plots followed by Bacillus megaterium (17.13 $\mathrm{kg} \mathrm{ha}^{-1}$ ) and Trichoderma viride (16.51 kg ha-1). Whereas significantly lower available phosphorus per plot were noted in uninoculated control. Similarly, graded levels of zinc in the form of zinc sulphate also increase the available phosphorus with each incremental dose up to $30 \mathrm{~kg} \mathrm{ZnSO}_{4} \mathrm{ha}^{-1}$. The available phosphorus as influenced by zinc application ranged from 14 to $18 \mathrm{~kg} \mathrm{ha}^{-1}$. Interaction effect of zinc mobilizing cultures and zinc levels on available phosphorus from soil shown in Table 1a.Significantly highest available phosphorus in Pseudomonas striata $\mathrm{X} \mathrm{ZnSO}_{4} 30 \mathrm{~kg} \mathrm{ha}^{-1}\left(19.30 \mathrm{~kg} \mathrm{ha}^{-1}\right)$ it was found at par with Trichoderma viride $\mathrm{X} \mathrm{ZnSO}_{4} 30 \mathrm{~kg} \mathrm{ha}^{-1}$ (18.71 $\left.\mathrm{kg} \mathrm{ha}^{-1}\right)$. However the lower value of available phosphorus (12.91 $\mathrm{kg} \mathrm{ha}^{-1}$ ) was recorded in uninoculated control.

Both plant roots and soil microorganisms alter and are affected by soil chemical and physical properties in the rhizosphere. Among the factor affecting soil $\mathrm{P}$ availability root exudates, such as organic acids, $\mathrm{H}$ ions, sugar and phosphatase facilitates the solubilization and desorption of mineral P. Alterations in composition and quantity root exudates through the introduction of new genetic traits may therefore direct affects processes such as mineral $\mathrm{P}$ or fixed $\mathrm{P}$ solubilization or indirectly affect the availability of $\mathrm{P}$ through changes in the activity of rhizosphere microorganisms. Thus, in our case it can be presumed that $\mathrm{P}$ availability was enhanced because of changes in rhizospheric conditions under microbial influence.

Our findings are also confirmed with the results of Egamberdiyeva et al. (2004) ${ }^{[6]}$ who observed the positive influence of P-solubilizers inoculation on soil available $\mathrm{P}$ and observed that phosphate solubilizers increased the available $\mathrm{P}$ in the soil. Further, Jayant Raman, (2012) ${ }^{[11]}$ also reported that Pseudomonas striata can solubilize the extra phosphorus. Similarly Bodkhe et al. (2014a) ${ }^{[5]}$ observed that the $100 \%$ $\mathrm{RDF}$ and dual inoculation treated plots had highest increase in available phosphorus which might be due to PSB secretes different organic acids like citric and mallic acid which act on insoluble phosphate $\left(\mathrm{PO}_{4}\right)$ to convert them into soluble phosphate $\left(\mathrm{H}_{2} \mathrm{PO}_{4}\right)$ near the root of the plant and hence availability of phosphorus increased. These beneficial bacteria enhances plant growth by improving soil nutrient status, secreting plant growth regulators as reported by Rizvi et al. (2013) [16], Afzal et al. (2013) ${ }^{[2]}$ and Kumar et al. (2014) ${ }^{[13]}$.

\section{Potassium}

In Table 1 shows that availability of potassium is significantly influenced by various treatments of zinc solubilizing microbial inoculants in spinach in which significantly highest 
value for potassium availability in Pseudomonas striata treated plots which is $\left(634.86 \mathrm{~kg} \mathrm{ha}^{-1}\right)$ followed by Bacillus megaterium (623.74 $\mathrm{kg} \mathrm{ha}^{-1}$ ) and Trichoderma viride (605.07 $\left.\mathrm{kg} \mathrm{ha}{ }^{-1}\right)$. Whereas, significantly lower available phosphorus per plot were noted in uninoculated control. Similarly, graded levels of zinc in the form of zinc sulphate also increase the available potassium with each incremental dose up to $30 \mathrm{~kg}$ $\mathrm{ZnSO}_{4} \mathrm{ha}^{-1}$. The available potassium as influenced by zinc application ranged from 579.45 to $641.79 \mathrm{~kg} \mathrm{ha}^{-1}$.

Interaction effect of zinc solubilizing microbial cultures and zinc levels on available potassium from soil shown in Table 1a.Significantly highest available potassium in Pseudomonas striata $\mathrm{X} \mathrm{ZnSO}_{4} 30 \mathrm{~kg} \mathrm{ha}^{-1}\left(657.18 \mathrm{~kg} \mathrm{ha}^{-1}\right)$ it was found at par with Bacillus megaterium X $\mathrm{ZnSO}_{4} 30 \mathrm{~kg} \mathrm{ha}^{-1}(651.52 \mathrm{~kg}$ $\left.\mathrm{ha}^{-1}\right)$. However the lower value of available potassium (517.43 $\mathrm{kg} \mathrm{ha}^{-1}$ ) was recorded in uninoculated control.

Microorganisms are able to mobilize metals by formation organic or inorganic acids (eg. citric and mallic acid) by oxidation and reduction reaction and by the secretion of complexion agents. Contents of organic acids released in the rhizoshere could be responsible for increased $\mathrm{K}$ solubilization. The marked effect of FYM + ZSB on turmeric rhizome yield might have been attributed to the direct role played by zinc solubilizer on enhancing the availability of not only zinc but also potassium (Kumar et al. 2014) ${ }^{[13]}$.

\section{Sulphur}

The data presented in Table 1 shows significant increase in available sulphur in soil after harvest of spinach with zinc solubilizers as compare to control. Significantly highest value of available sulphur is in Pseudomonas striata treated plot which is $11.04 \mathrm{mg} \mathrm{kg}^{-1}$ followed by Bacillus megaterium $10.69 \mathrm{mg} \mathrm{kg}^{-1}$ treated plot is at par with Trichoderma viride $10.61 \mathrm{mg} \mathrm{kg}^{-1}$.Whereas, significantly lower available sulphur per plot were noted in uninoculated control. Similarly, graded levels of zinc in the form of zinc sulphate also increase the available sulphur with each incremental dose up to $30 \mathrm{~kg}$ $\mathrm{ZnSO}_{4} \mathrm{~kg} \mathrm{ha}^{-1}$. The value of available sulphur for $30 \mathrm{~kg}$ $\mathrm{ZnSO}_{4} \mathrm{ha}^{-1}$ is $10.90 \mathrm{mg} \mathrm{kg}^{-1}$.

Interaction effect of zinc solubilizing microbial cultures and zinc levels on available sulphur from soil shown in Table 1a. Significantly highest available sulphur in Trichoderma viride $\mathrm{X} \mathrm{ZnSO}_{4} 30 \mathrm{~kg} \mathrm{ha}^{-1}\left(11.33 \mathrm{mg} \mathrm{ha}^{-1}\right)$ it was found at par with Bacillus megaterium $\mathrm{X} \mathrm{ZnSO}_{4} 30 \mathrm{~kg} \mathrm{ha}^{-1}$ (11.32 mg ha-1).
However the lower value of available sulphur $\left(8.30 \mathrm{mg} \mathrm{ha}^{-1}\right)$ was recorded in uninoculated control.

Due to application of $\mathrm{P}$ solubilizers, there was greater mobilization of insoluble phosphorus along with enhanced transport of soil nutrients within the plant system. Increasing $S$ availability due to application of $P$ solubilizers could be due to greater root proliferation and increasing activity of sulphur solubilizing bacteria. It may also attribute to the contribution of sulphur from single super phosphate which was used as a source of phosphorus. These results are in agreement with the findings of Trivedi et al. (1997) ${ }^{[19]}$ and Pasricha and sarkar (2002).

\section{DTPA extractable zinc}

The content of DTPA $\mathrm{Zn}$ in soil showed significant increase under all microbial inoculated treatments compared to control treatment. The data pertaining to periodical changes in DTPA $\mathrm{Zn}$ in soil is narrated in Table 2 and depicted in Fig.1. Zinc mobilizing cultures influenced the DTPA zinc which ranged from 0.38 to $0.64 \mathrm{mg} \mathrm{kg}^{-1}$ showing significantly higher DTPA zinc in Pseudomonas striata treated plots follows by Bacillus megaterium and Trichoderma viride. Whereas, significantly lower DTPA zinc per plot were noted in uninoculated control. Similarly, increase in zinc content in soil with application of graded levels of zinc in the form of zinc sulphate also increase the DTPA zinc with each incremental dose up to $30 \mathrm{~kg} \mathrm{ZnSO}_{4}$ $\mathrm{kg} \mathrm{ha}^{-1}$.

Interaction effect of zinc solubilizers and zinc levels on DTPA $\mathrm{Zn}$ in Table 2a. Showing significantly the highest build-up of soil DTPA Zn was noticed under in Pseudomonas striata X ZnSO $30 \mathrm{~kg} \mathrm{ha}^{-1}\left(0.815 \mathrm{mg} \mathrm{kg}^{-1}\right)$ followed by Bacillus megaterium $\mathrm{X} \mathrm{ZnSO}_{4} 30 \mathrm{~kg} \mathrm{ha}^{-1}\left(0.718 \mathrm{mg} \mathrm{kg}^{-1}\right)$ it was found at par with Trichoderma viride $\mathrm{X} \mathrm{ZnSO}_{4} 30 \mathrm{~kg}^{-}$ ${ }^{1}\left(0.683 \mathrm{mg} \mathrm{kg}^{-1}\right)$. However the lower values of DTPA zinc $\left(0.296 \mathrm{mg} \mathrm{kg}^{-1}\right)$ was recorded in uninoculated control plots.

Mechanisms employed by different solubilizers in enhancing $\mathrm{Zn}$ availability by solubilization and chelation of minerals can increase plant metabolism leading to the enhancement of plant physiological activity and the development of the root system with production of some organic acids in the rhizophere such as gluconic, citric and/or fumeric acids by solubilizers which decrease soil $\mathrm{pH}$, lead to increase solubility of the insoluble compound and availability of micronutrients like zinc.

Table 2: Effect of zinc solubilizing cultures and zinc levels on DTPA micronutrient in soil after harvest of spinach

\begin{tabular}{|c|c|c|c|c|}
\hline Treatments & DTPA Zn $\left(\mathrm{mg} \mathrm{kg}^{-1}\right)$ & DTPA Fe $\left(\mathrm{mg} \mathrm{kg}^{-1}\right)$ & DTPA Cu $\left(\mathrm{mg} \mathrm{kg}^{-1}\right)$ & DTPA Mn $\left(\mathrm{mg} \mathrm{kg}^{-1}\right)$ \\
\hline \multicolumn{5}{|l|}{ Zinc solubilizers (S) } \\
\hline S0: Control & 0.38 & 2.28 & 0.88 & 7.31 \\
\hline S1: Pseudomonas striata & 0.64 & 3.05 & 0.96 & 7.74 \\
\hline S2: Trichoderma viride & 0.51 & 2.53 & 0.92 & 7.58 \\
\hline S3: Bacillus megaterium & 0.55 & 2.68 & 0.94 & 7.66 \\
\hline S.Em. \pm & 0.01 & 0.03 & 0.007 & 0.06 \\
\hline C.D. at $5 \%$ & 0.03 & 0.10 & 0.02 & 0.19 \\
\hline \multicolumn{5}{|l|}{ Levels of $\mathrm{ZnSO}_{4}(\mathrm{Zn})$} \\
\hline $\mathrm{Zn0}: \mathrm{ZnSO}_{4} 0 \mathrm{~kg} \mathrm{ha}^{-1}$ & 0.38 & 2.43 & 0.85 & 7.14 \\
\hline $\mathrm{Zn} 1: \mathrm{ZnSO}_{4} 10 \mathrm{~kg} \mathrm{ha}^{-1}$ & 0.44 & 2.51 & 0.92 & 7.51 \\
\hline $\mathrm{Zn} 2: \mathrm{ZnSO}_{4} 20 \mathrm{~kg} \mathrm{ha}^{-1}$ & 0.57 & 2.67 & 0.94 & 7.73 \\
\hline $\mathrm{Zn} 3: \mathrm{ZnSO}_{4} 30 \mathrm{~kg} \mathrm{ha}^{-1}$ & 0.68 & 2.94 & 0.98 & 7.92 \\
\hline S.Em. \pm & 0.01 & 0.03 & 0.007 & 0.06 \\
\hline C.D. at $5 \%$ & 0.03 & 0.10 & 0.02 & 0.19 \\
\hline \multicolumn{5}{|l|}{ Interaction (SxZn) } \\
\hline S.Em. \pm & 0.02 & 0.07 & 0.01 & 0.13 \\
\hline C.D. at $5 \%$ & 0.07 & 0.21 & 0.03 & 0.39 \\
\hline
\end{tabular}


Further, Kumar et al. (2004) ${ }^{[12]}$ also reported that the marked effect of FYM + ZSB on turmeric rhizome yield might have attributed in the direct role played by zinc solubilizer on enhancing the availability of Zn. Similarly, Imran et al.
(2014) ${ }^{[10]}$ also observed that sustainable increase in soil bioavailable content of zinc has been reported in fungal inoculated soils as compared to uninoculated soils.

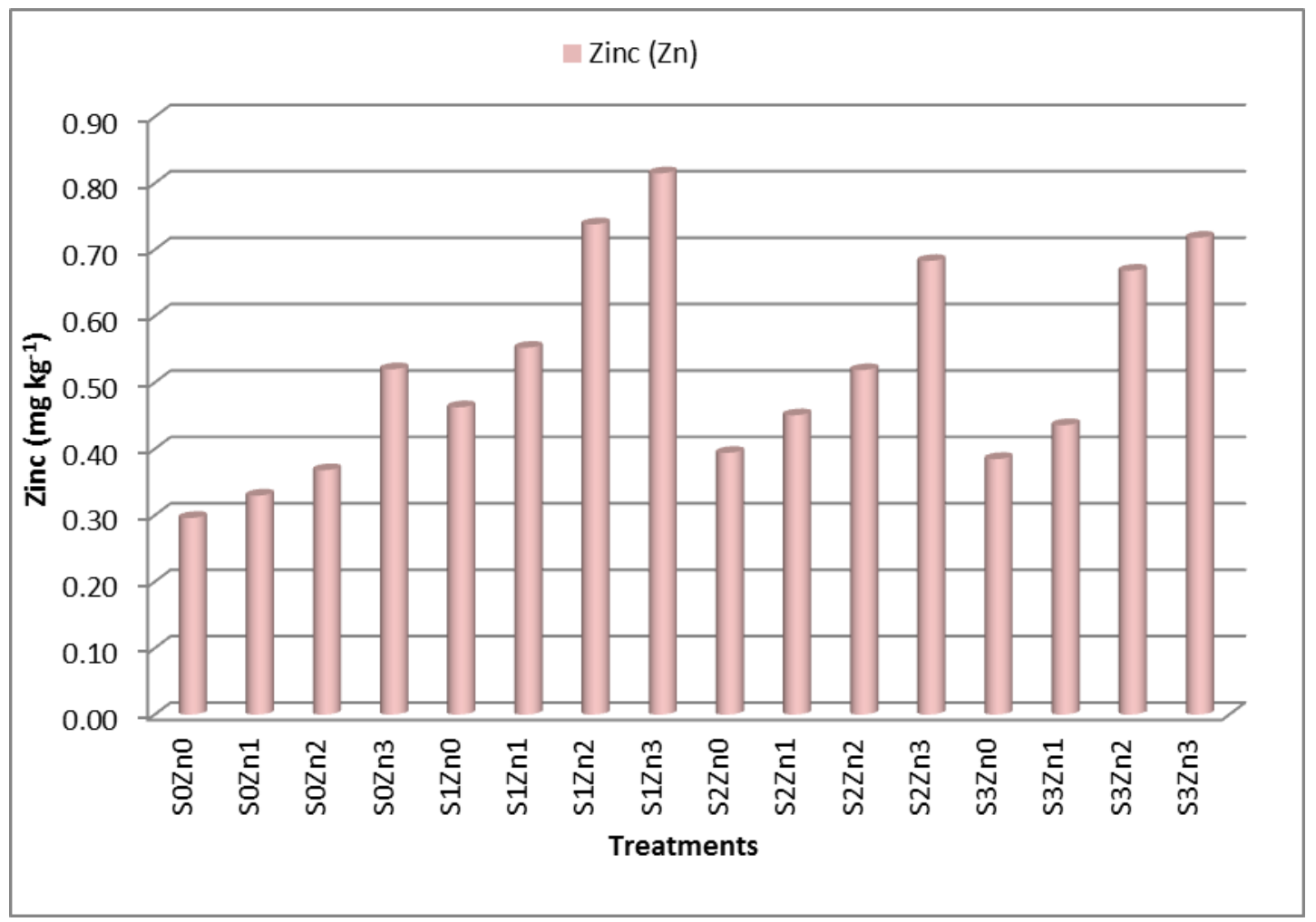

Fig. 1: Interaction effect of zinc solubilizers and levels of zinc on zinc availability in soil.

\section{DTPA extractable iron}

Results narrated in Table 2 related to DTPA iron in spinach indicate significant effect of zinc solubilizers and graded level of zinc. The zinc solubilizing cultures influenced the DTPA iron which ranged from 2.28 to $3.05 \mathrm{mg} \mathrm{kg}^{-1}$ showing significantly higher DTPA iron in treatment Pseudomonas striata treated plots followed by Bacillus megaterium and Trichoderma viride. Whereas, significantly lower DTPA iron per plot were noted in uninoculated control. Similarly, graded levels of zinc in the form of zinc sulphate also increased the DTPA iron with each incremental dose up to $30 \mathrm{~kg} \mathrm{ZnSO}_{4} \mathrm{ha}^{-}$ ${ }^{1}$.The DTPA iron as influenced by zinc application ranged between 2.43 to $2.94 \mathrm{mg} \mathrm{kg}^{-1}$.

Interaction effect of zinc solubilizers and zinc levels in Table 2a. Showing significantly the highest DTPA iron was noticed under in Pseudomonas striata $\mathrm{X} \mathrm{ZnSO}_{4} 30 \mathrm{~kg} \mathrm{ha}^{-1}(3.69 \mathrm{mg}$ $\mathrm{kg}^{-1}$ ) followed Bacillus megaterium $\mathrm{X} \mathrm{ZnSO}_{4} 30 \mathrm{~kg} \mathrm{ha}^{-1}(2.89$ $\mathrm{mg} \mathrm{kg}^{-1}$ ) it was found at par with Trichoderma viride $\mathrm{X}$ $\mathrm{ZnSO}_{4} 30 \mathrm{~kg} \mathrm{ha}^{-1}$. However the lower values of DTPA iron ( $2.14 \mathrm{mg} \mathrm{kg}^{-1}$ ) was recorded in without zinc application.

Microorganisms are able to mobilize metals by formation of organic or inorganic acids (citric acid, sulphuric acid) by oxidation and reduction processes and by the excreation of complexion agents. Contents of organic acids released in the rhizosphere could be responsible for increased $\mathrm{Fe}$ solubilization. As earlier reported, the release of organic acid that both sequester cation and acidity the microenvironment near roots is thought to be a major mechanism of solubilization of $\mathrm{P}$ as well as Fe in soils. The similar results were quoted by Birgita et al. (2000) ${ }^{[4]}$, Kumar et al. (2004) ${ }^{[12]}$ and Adriana et al. $(2010)^{[1]}$.

\section{DTPA extractable copper}

A perusal of data given in Table 2 revealed that DTPA extractable copper content in soil was influenced significantly with different zinc solubilizing microbial strains. Zinc solubilizers influenced the DTPA copper which ranged from 0.88 to $0.96 \mathrm{mg} \mathrm{kg}^{-1}$ have showing significantly higher DTPA copper in treatment Pseudomonas striata treated plots follows by Bacillus megaterium and Trichoderma viride. Whereas, significantly lower DTPA copper per plot were noted in uninoculated control. Similarly, applied zinc levels in the form of zinc sulphate also increase the DTPA copper with each incremental dose up to $30 \mathrm{~kg} \mathrm{ZnSO}_{4} \mathrm{ha}^{-1}$. The DTPA copper as influenced by $\mathrm{Zn}$ application ranged from 0.85 to $0.98 \mathrm{mg} \mathrm{kg}^{-1}$.

Interaction effect of zinc solubilizers and zinc levels on DTPA $\mathrm{Cu}$ in Table 2a. Showing significantly the highest DTPA copper was noticed under in Pseudomonas striata $\mathrm{X}$ $\mathrm{ZnSO}_{4} 30 \mathrm{~kg} \mathrm{ha}^{-1}\left(1.03 \mathrm{mg} \mathrm{kg}^{-1}\right)$ it was found at par with both Trichoderma viride and Bacillus megaterium $\mathrm{X} \mathrm{ZnSO}_{4} 30 \mathrm{~kg}$ $\mathrm{ha}^{-1}$. However the lower values of DTPA copper $(0.77 \mathrm{mg} \mathrm{kg}-$ $\left.{ }^{1}\right)$ was recorded in without microbial culture and zinc apllication. 
Table 2a: Interaction effect of zinc solubilizers and levels of zinc on DTPA micronutrient in soil after harvest of spinach

\begin{tabular}{|c|c|c|c|c|c|}
\hline Treatments & Zn0:ZnSO $40 \mathrm{~kg} \mathrm{ha}^{-1}$ & Zn1:ZnSO 410 kg ha-1 $^{-1}$ & $\mathrm{Zn2:ZnSO}_{4} 20 \mathrm{~kg} \mathrm{ha}^{-1}$ & Zn3:ZnSO $430 \mathrm{~kg} \mathrm{ha}^{-1}$ & Mean \\
\hline \multicolumn{6}{|c|}{ DTPA Zn $\left(\mathrm{mg} \mathrm{kg}^{-1}\right)$} \\
\hline S0: Control & 0.296 & 0.330 & 0.368 & 0.520 & 0.378 \\
\hline S1: Pseudomonas striata & 0.463 & 0.552 & 0.738 & 0.815 & 0.642 \\
\hline S2: Trichoderma viride & 0.394 & 0.451 & 0.519 & 0.683 & 0.512 \\
\hline S3: Bacillus megaterium & 0.385 & 0.436 & 0.668 & 0.718 & 0.552 \\
\hline Mean & 0.384 & 0.442 & 0.573 & 0.684 & \\
\hline Interaction & $\mathbf{S}$ & $\mathbf{Z n}$ & SXZn & & \\
\hline SEm+ & 0.013 & 0.013 & 0.026 & & \\
\hline CD at $5 \%$ & 0.038 & 0.038 & 0.076 & & \\
\hline \multicolumn{6}{|c|}{ DTPA Fe (mg kg-1) } \\
\hline S0: Control & 2.14 & 2.17 & 2.27 & 2.55 & 2.281 \\
\hline S1: Pseudomonas striata & 2.57 & 2.76 & 3.18 & 3.69 & 3.050 \\
\hline S2: Trichoderma viride & 2.47 & 2.49 & 2.54 & 2.62 & 2.531 \\
\hline S3: Bacillus megaterium & 2.54 & 2.60 & 2.70 & 2.89 & 2.683 \\
\hline Mean & 2.430 & 2.505 & 2.673 & 2.937 & \\
\hline Interaction & $\mathbf{S}$ & Zn & SXZn & & \\
\hline SEm+ & 0.037 & 0.037 & 0.074 & & \\
\hline $\mathrm{CD}$ at $5 \%$ & 0.106 & 0.106 & 0.213 & & \\
\hline \multicolumn{6}{|c|}{ DTPA Cu (mg kg-1 } \\
\hline S0: Control & 0.77 & 0.88 & 0.92 & 0.95 & 0.878 \\
\hline S1: Pseudomonas striata & 0.89 & 0.93 & 0.97 & 1.03 & 0.956 \\
\hline S2: Trichoderma viride & 0.86 & 0.92 & 0.93 & 0.97 & 0.918 \\
\hline S3: Bacillus megaterium & 0.88 & 0.93 & 0.95 & 0.98 & 0.937 \\
\hline Mean & 0.850 & 0.915 & 0.944 & 0.979 & \\
\hline Interaction & $\mathbf{S}$ & Zn & SXZn & & \\
\hline SEm+ & 0.007 & 0.007 & 0.014 & & \\
\hline CD at $5 \%$ & 0.02 & 0.02 & 0.039 & & \\
\hline \multicolumn{6}{|c|}{ DTPA Mn(mg kg-1) } \\
\hline S0: Control & 6.44 & 7.22 & 7.66 & 7.93 & 7.314 \\
\hline S1: Pseudomonas striata & 7.52 & 7.66 & 7.75 & 8.04 & 7.743 \\
\hline S2: Trichoderma viride & 7.41 & 7.56 & 7.64 & 7.73 & 7.583 \\
\hline S3: Bacillus megaterium & 7.19 & 7.58 & 7.86 & 7.99 & 7.655 \\
\hline Mean & 7.140 & 7.506 & 7.727 & 7.923 & \\
\hline Interaction & $\mathbf{S}$ & Zn & SXZn & & \\
\hline SEm+ & 0.068 & 0.068 & 0.135 & & \\
\hline $\mathrm{CD}$ at $5 \%$ & 0.196 & 0.196 & 0.391 & & \\
\hline
\end{tabular}

These results are in line of findings of Jayant Raman (2012) ${ }^{[11]}$ who found the highest availability of $\mathrm{Cu}$ in soil with the inoculation of treatment combination of Pseudomonas striata + Trichoderma viride and Azotobacter chroococcum. The release of organic acid that both sequester cation and acidity the microenvironment near roots is thought to be a major mechanism of solubilization of $\mathrm{Cu}$ in soils as reported by Altomare et al. (1999) ${ }^{[3]}$.

\section{DTPA extractable manganese}

Inoculation of zinc solubilizing microbial inoculants enhanced the DTPA manganese content in soil as compared to initial values. Zinc mobilizing cultures influenced the DTPA manganese which ranged between 7.31 to $7.74 \mathrm{mg} \mathrm{kg}$ showing significantly higher DTPA manganese in Pseudomonas striata treated plots follows by Bacillus megaterium and Trichoderma viride. Whereas, significantly lower DTPA manganese per plot were noted in control plots. Similarly, application of zinc levles in the form of zinc sulphate also increased the DTPA manganese with each incremental dose up to $30 \mathrm{~kg} \mathrm{ZnSO}_{4} \mathrm{ha}^{-1}$. The DTPA manganese as influenced by $\mathrm{Zn}$ application ranged from 7.14 to $7.92 \mathrm{mg} \mathrm{kg}^{-1}$.

Interaction effect of zinc solubilizers and zinc levels on DTPA manganese in Table 2a. Increase the DTPA manganese significantly synergistic effect of each factor was recorded on each other showing significantly the highest DTPA manganese was noticed under in Pseudomonas striata $\mathrm{X}$
$\mathrm{ZnSO}_{4} 30 \mathrm{~kg} \mathrm{ha}^{-1}(8.04 \mathrm{mg} \mathrm{kg}-1)$ it was found at par with Bacillus megaterium $\mathrm{X} \mathrm{ZnSO}_{4} 30 \mathrm{~kg} \mathrm{ha}^{-1}$. However, the lower values of DTPA manganese $\left(6.44 \mathrm{mg} \mathrm{kg}^{-1}\right)$ was recorded in without microbial culture and zinc application.

The DTPA Mn increased might be due to transformation of oxidized form of $\mathrm{Mn}$ to reduced form. Similar results are also registered by Altomare et al. (1999) [3]. Kumar et al. (2004) ${ }^{[12]}$ reported that the availability of $\mathrm{Mn}$ in the soil, brought on the positive effect of $\mathrm{Zn}$ and $\mathrm{Fe}$ added alone or along with FYM and FYM + ZSB.

\section{Conclusion}

Significantly maximum nutrient availability in soil after harvest of spinach crop was also registered with zinc solubilizers. Significantly highest values of available $\mathrm{N}, \mathrm{P}_{2} \mathrm{O}_{5}$, $\mathrm{K}_{2} \mathrm{O}$ and $\mathrm{S}$ were recorded maximum in treatment receiving the inoculation of Psuedomonas striata $+30 \mathrm{~kg} \mathrm{ZnSO}_{4} \mathrm{ha}^{-1}$ over rest of the treatments. The DTPA micronutrients ( $\mathrm{Zn}, \mathrm{Fe}$, $\mathrm{Mn}$ and $\mathrm{Cu}$ ) in soil after harvest of spinach were also found significantly influenced by bioinoculants. DTPA micronutrients $(\mathrm{Zn}, \mathrm{Fe}, \mathrm{Mn}$ and $\mathrm{Cu})$ were note maximum in treatment receiving the inoculation of Pseudomonas striata + $30 \mathrm{~kg} \mathrm{ZnSO} 4 \mathrm{ha}^{-1}$.

\section{References-}

1. Adriana I, Stefanescu R, Duncianu M. Bio-solubilisation capacity of Bacillus megaterium strain of some 
micronutrients from the polluted soil. Cercetări Agronomice În Moldova. 2010; 142 (2):49-52.

2. Afzal A, Khokhar SN, Jabeen B, Asad SA. Phosphate solubilizing bacteria associated with vegetables roots in different ecologies. Pak. J Bot. 2013; 45(S1):535-544.

3. Altomare C, Norvell WA, Bjorkman TB, Harman GE. Solubilization of phosphates and micronutrients by the Plant-Growth-Promoting and Bio control fungus Trichoderma harzianum Rifai: 1295-22. Appl. Environ. Microbiol, 1999, 2926-2933.

4. Birgita EK, Laura JL, Guvens S, Susan LB. Rates of bacteria promoted solubilization of $\mathrm{Fe}$ from minerals: a review of problems and approaches. Chem. Geol. 2000; 169:357-370.

5. Bodkhe AA, Syed Ismail, Syed Javed Jani. Effect of chemical fertilizers and microbial inoculants on soybean (Glycine max) - safflower (Carthamus tinctorius) cropping pattern. Green Farming. 2014; 5(3):341-345.

6. Egamberdiyea D, Qarshieva D, Davranov K. The use of Bradyrhizobium to enhance growth and yield of soybean in calcareous soil in Uzbekistan. J Plant Growth Regulation. 2004; 23(1):54-57.

7. Gadd GM. Geomycology: Biogeochemical transformations of rocks, minerals, metals and radionuclides by fungi, bio weathering and bioremediation. Mycol. Res. 2007; 111:3-49.

8. Goteti PK, Amalraj ELD, Desai S, Shaik MHA. Prospective zinc solubilising bacteria for enhanced nutrient uptake and growth promotion in maize (Zea mays L.). Int. J Microbiol, 2013, 1-7.

9. Hafeez B, Khanif YM, Saleem M. Role of Zinc in Plant Nutrition- A Review. American Journal of Experimental Agriculture. 2013; 3(2):374-391.

10. Imran M, Arshad M, Khalid A, Kanwal S, Crowley DE. Perspectives of rhizosphere microflora for improving Znbio availability and acquisition by higher plants. Int. J Agric. Biol. 2014; 16:653-662 .

11. Jayant Raman. Response of Azotobacter, Pseudomonas and Trichoderma on growth and apple seedling. Int. conference on Biol. Life Sci. 2012; 40:83-90.

12. Kumar P, Kumar AK, Rattan RK. Chemical forms of zinc in soils and their contribution to available pool. Journal of The Indian Society of soil science. 2004; 55:421-425.

13. Kumar PS, Aruna Geetha S, Savithri P, Jagadeeswaran R, Ragunath K. Effect of $\mathrm{Zn}$ enriched organic manures and zinc solubilizer application on the yield curcumin content and nutrient status of soil under turmeric cultivation. J Appl. Hortic. 2014; 6(2):82-86.

14. Mahdi SS, Dar SA, Ahmad S, Hassan GI. Zinc availability - A major issue in agriculture. Res. J Agri. Sci. 2010; 3:78-79.

15. Panse UG, Sukhatme PV. Statistical Methods for Agricultural Workers. I.C.A.R. Pub., New Delhi, 1985.

16. Rizvi R, Mahmood I, Tiyagi SA. Potential Role of Organic Matters and Phosphate Solubilizing Bacteria (PSB) on the Growth and Productivity of Fenugreek. J Agri. Sci. Tech. 2013; 15:639-647.

17. Sable P, Ismail Syed, Pawar A. Effect of different microbial inoculants on yield, microbial population and chemical properties in soil of groundnut grown on vertisol. International Journal of Microbiology Research. 2016b; 9(1):831-833.
18. Simine CD, Sayed JA, Gadd GM. Solubilization of zinc phosphate by a strain Pseudomonas fluorescens isolated from a forest soil. Biol Fertil Soils. 1998; 28:87-94.

19. Trivedi SK, Singh V, Shinde CP, Tomar RA. Effect of continuous use of $\mathrm{N}, \mathrm{P}$ and $\mathrm{S}$ to Blackgram in Blackgram-mustard crop sequence. Crop Res. 1997; 13(1):73-79. 